\title{
PENERAPAN KEAMANAN DAN SANITASI PANGAN PADA PRODUKSI MINUMAN SEHAT KACANG-KACANGAN UMKM JUKAJO SUKSES MULIA DI KABUPATEN TANGERANG
}

Implementation of Sanitation and Food Safety of Beans-Based Healthy Drinks Production at The Jukajo Sukses Mulia Home Industry in Tangerang Regency

\author{
Angelina Rianti ${ }^{1)}$, Alvin Christopher ${ }^{1)}$, Devi Lestari ${ }^{1)}$, Warsono El Kiyat ${ }^{1) *}$ \\ ${ }^{10}$ Departemen Teknologi Pangan, Fakultas Ilmu Hayati, Universitas Surya \\ Jl. MH. Thamrin Km 2.7, Banten 15117, Indonesia \\ *E-mail: warsono.el.kiyat@gmail.com
}

\begin{abstract}
Food contamination is not desired by producers or consumers. Safety factor is important in order to prevent side effects due to food contamination that can endanger health. Contamination in food occurs from small to large industries. Sanitation also plays an important role in many industries including the food industry. The research subject was a home industry of beans-based healthy drinks (BBHD), such as mung beans, soybeans, and red beanss drinks at Jukajo Sukses Mulia home industry in Tangerang Regency. This study was conducted to determine the level of security, sanitation, and sources of contamination in the BBHD industry Tangerang Regency. This study was carried out through observation and interview with the owner and the workers of Jukajo Sukses Mulia home industry. The result showed that the level of security and sanitation in the production environment was quite good. The potential source of contamination in the production process was the hygiene of the employees and the cleanliness of the production equipment. The critical control points were be located in filling, chilling, and storing processes. Total plate count value of mung beans, soybeans, and cashwes drinks were too numerous to count (TNTC), $3 \times 10^{3}$, and $2 \times 10^{2} \mathrm{CFU} / \mathrm{ml}$, respectively.
\end{abstract}

Keywords: food safety, healthy drink, home industry, sanitation

\section{PENDAHULUAN}

Adanya cemaran pada produk pangan dapat mengakibatkan penyakit berbahaya hingga kematian. Pada salah satu artikel dari Pikiran Rakyat, pada tahun 2013 terdapat 10.700 kasus keracunan pangan yang mengakibatkan kematian di Indonesia (Effendi, 2017). Selain itu, pada tahun 2016 terdapat data yang menunjukkan sekitar $14,9 \%$ dari 26.537 sampel pangan tidak memenuhi syarat. Produk pangan tersebut dikatakan tidak memenuhi syarat karena mengandung bahan berbahaya, cemaran mikroba atau bahan tambahan pangan (BTP) yang kadarnya melebihi batas maksimum yang diizinkan. Menurut Putri (2017), pada tahun 2011-2015, produk makanan yang tidak memenuhi syarat mengalami peningkatan sekitar 35 persen.
Kemudian, pada tahun 2013-2015, laporan mengenai keracunan makanan yang serius meningkat dari 48 menjadi 61 kasus di 34 provinsi. Oleh karena itu, untuk mengurangi kontaminasi pada proses produksi di suatu industri, hal tersebut harus diperhatikan dengan baik, yaitu dengan menerapkan GMP (good manufacturing practices) dan HACCP (hazard analysis and critical control point) sehingga kasus keracunan makanan dapat dikurangi.

Salah satu bagian dari GMP adalah sanitasi. Sanitasi memegang peranan penting dalam berbagai industri termasuk industri pangan. Sanitasi pangan menentukan seberapa higienis suatu produk dihasilkan. Sanitasi juga mendukung program HACCP yang diterapkan dalam industri pangan. 
Biasanya, kalangan industri pangan skala besar telah menerapkan HACCP, namun masih banyak industri skala rumah tangga yang belum menerapkannya. Tentu saja hal tersebut menjadi perhatian khusus karena produk yang dihasilkan belum terjamin keamanannya secara maksimal. Risiko keamanan pangan bagi konsumen sangatlah penting karena sudah terdapat regulasi yang mengaturnya. Oleh karena itu, pada penelitian ini dilakukan peninjauan pada industri skala rumah tangga.

Pada penelitian ini, industri yang dikaji penerapan keamanan dan sanitasinya yaitu home industry minuman sehat berupa pabrik pengolahan kacangkacangan seperti kacang hijau, kacang kedelai, dan kacang merahmenjadi jus siap minum di UMKM Jukajo Sukses Mulia. Industri ini dipilih karena minuman dari kacang-kacangan cukup digemari masyarakat karena rasanya yang manis, segar, dan menyehatkan. Akan tetapi, jika produsen tidak memperhatikan sanitasi saat proses produksi, maka konsumen dapat terkena dampak negatifnya.

\section{METODE PENELITIAN}

\section{Alat dan Bahan}

Alat yang digunakan pada penelitian ini adalah form audit, cawan petri, autoklaf, mikropipet, labu erlenmeyer, bunsen, dan inkubator. Bahan yang digunakan pada penelitian ini adalah sampel minuman sehat, media Plate Count Agar (PCA), dan saline water.

\section{Teknik Pengumpulan Data}

Teknik pengumpulan data merupakan cara yang digunakan untuk memperoleh informasi yang berguna untuk analisis data. Teknik pengumpulan data yang digunakan dalam penelitian ini meliputi observasi lapangan, wawancara pada narasumber dan studi literatur.

\section{Observasi Lapangan}

Observasi lapangan dilakukan dengan mengamati setiap kegiatan yang dilakukan pada proses produksi di industri rumah tangga minuman sehat berupa minuman kacang hijau, kacang kedelai, dan kacang merah. Data-data yang diperoleh dicatat dengan sistematis untuk mengetahui gejala-gejala yang terjadi di lapangan.

Narasumber dalam penelitian ini adalah pihak manajemen atau karyawan industri rumah tangga minuman sehat minuman kacang hijau, kacang kedelai, dan kacang merah. Penelitian wawancara dan observasi bersifat saling melengkapi sehingga dapat diperoleh data yang lengkap.

\section{Studi Literatur}

Studi literatur dilakukan untuk memperkuat teori dan konsep yang digunakan dalam penelitian melalui publikasi ilmiah yang berkaitan dengan topik. Adapun referensi yang digunakan di antaranya jurnal ilmiah, buku, dan peraturan-peraturan lembaga pemerintah.

\section{Metode Analisis}

Analisis data yang dilakukan adalah analisis SSOP (Sanitation Standard Operating Procedure), HACCP (Hazard Analysis Critical Control Point), GMP (Good Manufacturing Practice). Selain itu juga dilakukan analisis cemaran mikroba pada produk.

\section{Analisis HACCP (CAC, 2003)}

Analisis HACCP dilakukan sebagai bentuk pemeriksaan apakah industri telah mengikuti standar keamanan pangan bertaraf internasional, mengingat CODEX menyarankan agar seluruh skala industri pangan sebaiknya dapat mengaplikasikan prinsip HACCP ini. Analisis HACCP yang dilakukan adalah penentuan titik kendali kritis (TKK) pada alur produksi. 


\section{Analisis GMP (BPOM, 2012a)}

Analisis GMP yang dimaksud adalah analisis sesuai dengan standar CPPB (cara produksi pangan yang baik). Analisis GMP dan SSOP dilakukan melalui form audit checklist GMP dan SSOP sesuai dengan Peraturan Kepala BPOM Nomor HK.03.1.23.04.12.2207 Tahun 2012 tentang Tata Cara Pemeriksaan Sarana Produksi Pangan Industri Rumah Tangga.

\section{Analisis Cemaran Mikroba (Sanders, 2012)}

Analisis cemaran mikroba dengan metode Angka Lempeng Total (ALT) pada produk minuman sehat kacang-kacangan. Pertama, sampel diencerkan terlebih dahulu kemudian diinokulasikan pada cawan berisi mediaPCA (Plate Count Agar). Cawan tersebut diinkubasi pada keadaan aerob, suhu $30^{\circ} \mathrm{C}$ selama 72 jam. Jumlah mikroorganisme per $\mathrm{ml}$ sampel dihitung dari jumlah koloni yang tumbuh pada cawan dengan jumlah di bawah 300 koloni. Adapun rumus perhitungannya yaitu:

koloni per $\mathrm{ml}=$ jumlah koloni per cawan $\mathrm{x} 1 /$ faktor pengenceran.

\section{HASIL DAN PEMBAHASAN}

\section{SSOP (Sanitation Standard Operating Procedure) pada Produksi Minuman Sehat Kacang-Kacangan}

Industri minuman sehat yang menjadi objek penelitian diproses dengan cara seperti Gambar 1. Bahan baku berupa kacang hijau, kacang kedelai dan kacang merah ditimbang dan dikemas sebelum dicuci. Pada proses pencucian digunakan air yang bersih dan mengalir untuk menghilangkan kotoran yang masih menempel pada bahan baku. Sebelum dilakukan penghancuran, kacang-kacangan dimasukkan ke dalam air mendidih sebanyak \pm 13 liter selama 40 menit. Setelah kacang matang, dilakukan penirisan untuk memisahkannya dengan air bekas pemasakan. Setelah itu, kacang dimasukkan ke dalam mesin penggiling untuk dihancurkan. Kacang yang telah digiling, kemudian disaring dengan ayakan ukuran 60 mesh.

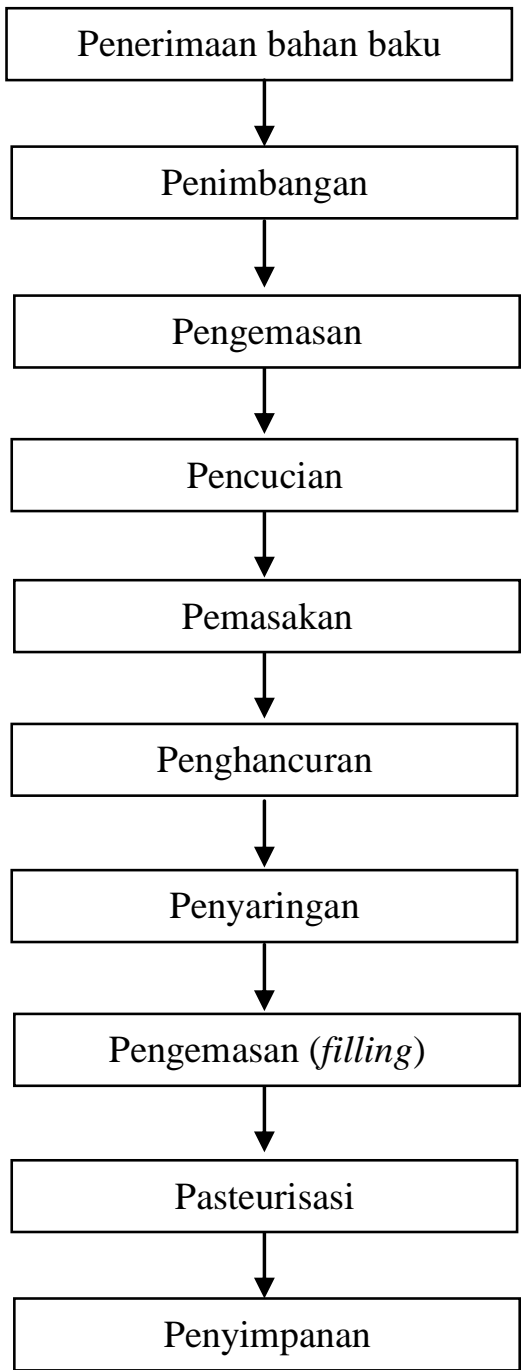

Gambar 1. Alur produksi minuman sehat-kacangkacangan

Hasil penggilingan kacang yang masih kasar akan digiling kembali untuk mendapatkan ukuran yang lebih halus sehingga lolos pada proses penyaringan. Kacang hasil penyaringan kemudian dikemas menggunakan filler dan dimasukkan ke dalam botol $350 \mathrm{ml}$. Setelah botol terisi sesuai volume yang sudah ditentukan, botol kemudian ditutup secara hermetis dengan mesin capping. Produk yang telah dikemas kemudian dimasukkan ke dalam keranjang dan 
direndam pada suhu $62^{\circ} \mathrm{C}$ selama 3 menit. Setelah itu, produk disimpan dalam ruang pendingin. Adapun Uraian SSOP pada lokasi produksi adalah sebagai berikut:

\section{Keamanan Air}

Cara mengawasi aspek keamanan air adalah dengan menguji air melalui laboratorium terakreditasi. Sumber air yang berupa es maka industri harus memantau dan memastikan bahwa es diperoleh dari air bersih. Apabila terjadi penyimpangan, perusahaan harus segera menindaklanjuti, misalnya menghentikan pendistribusian es dari produsen yang tidak kredibel. Pengawasan harus dilakukan secara berkala, mulai dari sehari-hari hingga secara periodik per bulan.

\section{Pencegahan Kontaminasi Silang}

Aspek kontaminasi silang dapat terjadi akibat kontak alat dengan produk ataupun antar bahan baku yang digunakan. Seharusnya, alat dibersihkan secara berkala (Kemenkes, 2011) menggunakan desinfektan tertentu seperti natrium hipoklorit dan glutaraldehid (Utami et al., 2016). Penyimpanan bahan baku yang berbeda jenisnya maupun dengan produk jadi, juga harus dipisahkan agar tidak terjadi kontaminasi silang. Praktek sanitasi pekerja juga harus diperhatikan untuk mencegah penularan virus atau penyakit atau mikroorganisme dari pekerja ke produk akhir. Jika terjadi penyimpangan, maka harus segera dilakukan tindakan pengamanan pada produk yang terkontaminasi dan mengevaluasi tempat penyimpanan bahan baku maupun produk akhir.

\section{Menjaga Fasilitas Pencuci Tangan,} Sanitasi dan Toilet

Sarana pencucian tangan diletakkan sebelum memasuki ruang produksi. Tempat sampah harus dilengkapi dengan penutup dan tidak boleh dibiarkan menumpuk. Apabila dalam ruang produksi pekerja tidak menggunakan alas kaki, maka sebaiknya disediakan fasilitas footbath untuk menjaga sanitasi di dalam ruangan produksi. Apabila terjadi penyimpangan, tindakan koreksi harus segera dilakukan, misalnya apabila sampah menumpuk harus segera dibuang. Pengawasan perlu dilakukan setiap harinya.

\section{Proteksi dari Bahan-Bahan Kontaminan}

Bahan baku dan alat produksi rentan terkontaminasi oleh berbagai sumber, seperti serangga, debu, bahkan dari pekerja. Pekerja yang berkontak dengan produk perlu diberi pelatihan mengenai tata cara penanganan produk yang baik dan benar. Bahan-bahan perlu dipisahkan dan dicuci dengan bersih, dan disimpan di tempat yang aman. Jika terjadi penyimpangan, bahan yang telah terkontaminasi perlu disingkirkan dan tidak boleh digunakan kembali.

\section{Pengendalian Kesehatan Karyawan}

Kesehatan karyawan memerlukan pengawasan secara berkala, khususnya karyawan yang bekerja di bagian produksi. Sebaiknya setiap karyawan, baik yang bekerja di bagian produksi maupun tidak, perlu diberi tunjangan kesehatan dan wajib memeriksakan kesehatan sebulan sekali sehingga kesehatan karyawan dapat dikontrol dengan baik. Apabila terjadi penyimpangan, karyawan yang menderita sakit ringan perlu diliburkan terlebih dahulu untuk beristirahat hingga kondisi tubuh karyawan tersebut normal kembali. Namun jika karyawan menderita penyakit yang akut, sebaiknya tidak diperbolehkan bekerja di bagian yang berhubungan dengan bagian produksi.

GMP (Good Manufacturing Practices) pada Produksi Minuman Sehat KacangKacangan

Lokasi dan Lingkungan Produksi

Menurut Kategori Ketidaksesuaian

BPOM No. HK.03.1.23.04.12.2207 tahun 
2012, kondisi di sekitar lokasi dan lingkungan produksi tergolong dalam kategori mayor. Lokasi di luar ruang produksi masih terawat, namun masih banyak ditemukan kelemahan seperti kucing yang berkeliaran di halaman lokasi produksi, terdapat perangkap tikus dan tikus di dekat tempat penyimpanan es. Lingkungan produksi berada dekat dengan kebun atau tanah kosong, sehingga seringkali serangga seperti lalat masuk ke lokasi produksi. Industri juga berlokasi di sekitar perumahan dengan sistem selokan yang berada di depan lokasi masih terbuka dan menimbulkan aroma yang tidak sedap. Selokan yang terbuka juga memicu adanya nyamuk dan binatang lainnya.

\section{Bangunan dan Fasilitas}

Bangunan dan fasilitas yang digunakan sebagai tempat produksi sudah cukup baik. Jalur keluar dan masuk sudah dibuat satu arah, sehingga para pekerja tidak dapat keluar masuk ruang produksi secara sembarangan. Sirkulasi udara di dalam ruang produksi juga merata karena didukung dengan sistem ventilasi udara yang cukup baik. Namun, pada industri rumah tangga tersebutmasih terdapat beberapa kekurangan pada ruang produksi berdasarkan peraturan BPOM (2011; 2012b), yaitu lantai ruang produksi belum menggunakan jenis lantai yang kedap air, batas lantai dengan dinding masih berbentuk siku-siku, belum adanya penutup lampu, serta peralatan toilet yang tidak lengkap. Selain itu, di antara ruang pencucian, ruang perendaman bahan baku, dan ruang penyimpanan tidak terdapat sekat pemisah, sehingga lantai menjadi basah dan licin.

\section{Peralatan Produksi}

Beberapa peralatan yang digunakan pada produksi yang perlu diperhatikan adalah baskom, gelas ukur, dan wadah penyimpanan lainnya. Baskom yang digunakan untuk menampung jus kacang hijau yang hendak dihaluskan (grinding) masih berbahan plastik, kemudian juga baskom diletakkan di bawah (berkontak langsung dengan lantai). Selain baskom, gelas ukur atau gelas takar yang digunakan juga masih berbahan plastik. Wadahwadah lain juga tidak disusun dan disimpan dengan rapi di tempat atau lemari yang bersih dan terlindung dari risiko kontaminasi.

\section{Suplai Air atau Sarana Penyediaan Air}

Kegiatan produksi yang dilakukan sehari-hari menggunakan jenis air bersih PAM untuk proses pencucian rutin dan menggunakan air heksagonal sebagai bahan baku air dalam produksi minuman kesehatan berbahan dasar kacang hijau, kacang kedelai, dan kacang merah tersebut. Air heksagonal diperoleh dari supplier yang sudah melewati pengujian laboratorium. Secara keseluruhan, suplai air pada industri rumah tangga minuman sehat berupa jus kacang sudah tergolong baik.

\section{Fasilitas dan Kegiatan Higiene dan Sanitasi}

Fasilitas dan kegiatan higiene dan sanitasi di sekitar lingkungan produksi tergolong dalam kategori kritis. Fasilitas toilet untuk karyawan berjumlah 2 ruangan, yaitu toilet pria dan wanita. Namun, beberapa peralatan yang mendukung kebersihan karyawan belum memenuhi kriteria berdasarkan peraturan BPOM (2012b), seperti tidak terdapat wastafel, sabun cuci tangan, dan pengering untuk karyawan mencuci tangan setelah menggunakan toilet. Peralatan kebersihan dan pelindung kaki, seperti sepatu boots telah disediakan, tetapi tidak tersedia bak pencuci atau sterilisasi kaki bagi orangorang yang hendak masuk ke dalam ruang produksi. Selain itu, di dalam ruang produksi, tidak terdapat kotak P3K (Pertolongan Pertama pada Kecelakaan) untuk menjadi alat pertolongan pertama apabila terjadi kecelakaan kerja pada karyawan. 


\section{Kesehatan dan Higiene Karyawan}

Industri telah mengadakan pelatihan mengenai GMP kepada para karyawan. Sayangnya, masih ditemukan karyawan yang tidak menerapkan aturan dengan benar, contohnya pekerja menggunakan sepatu boots saat keluar dari ruang produksi, pekerja tidak menggunakan sarung tangan saat melakukan proses pengemasan dan pelabelan, serta masih ada karyawan yang menggunakan hairnet yang tidak menutupi telinga dan dikenakan di luar area produksi. Pihak industri belum melakukan pengecekan apakah karyawan terbebas dari penyakit kulit atau penyakit menular lainnya.

\section{Pemeliharaan dan Program Higiene Sanitasi}

Pemeliharaan alat dengan cara pembersihan dilakukan setiap hari setelah sebelum proses produksi. Pembersihan dilakukan menggunakan air dan sabun pencuci biasa. Saluran atau pembuangan dalam tempat produksi belum dilengkapi dengan alat yang mempunyai katup untuk mencegah masuknya air ke dalam tempat produksi. Kendaraan yang digunakan untuk pengiriman selalu dibersihkan setiap kali selesai mendistribusikan produk kepada konsumen.

\section{Penyimpanan}

Produk yang sudah siap untuk didistribusikan disimpan terlebih dahulu di dalam ruang pendingin. Seharusnya, penyimpanan produk dilakukan pada suhu di bawah $10^{\circ} \mathrm{C}$,namun pada kenyataannya, suhu ruangan berada di atas $10^{\circ} \mathrm{C}$. Menurut BPOM (2011), penyimpanan dingin harus dilakukan pada suhu $0-8^{\circ} \mathrm{C}$. Suhu tersebut harus dipertahankan hingga produk siap didistribusikan untuk menjaga kondisi produk makanan/minuman.

\section{Pelabelan Pangan, Pengawasan oleh Penanggung Jawab dan Pelatihan Karyawan}

Produk minuman sehat berbahan dasar kacang hijau, kacang kedelai, dan kacang merah ini sudah memiliki nomor P-IRT dari Dinas Kesehatan. Produk akhir yang siap dipasarkan tidak dilakukan pemeriksaan ulang dan pengujian mutu sebelum diedarkan. Kualitas produk selama distribusi hanya bergantung pada penyimpanan produk dalam kotak es saat di perjalanan. Kontrol produksi seharusnya wajib dilakukan dengan melakukan pencatatan dan dokumentasi. Hingga saat ini, industri sudah memulai untuk melakukan pencatatan dan dokumentasi sebagai rekapitulasi dan data. Pencatatan dan dokumentasi dilakukan oleh kepala produksi/pegawai yang memegang kendali dan tanggung jawab di rumah produksi. Program pelatihan karyawan telah dilakukan berupa sosialiasi cara produksi pangan yang baik (CPPB). Namun, sejauh ini industri masih belum mengenal HACCP.

\section{Titik Kendali Kritis}

Berdasarkan alur proses produksi pada Gambar 1, terdapat tiga titik kendali kritis dalam produksi minuman sehat berbasis kacang-kacangan yang ditemukan. Titik kendali kritis tersebut terdapat pada proses filling, pendinginan dan penyimpanan produk.

\section{Proses Filling Dilakukan pada Suhu 60- $65^{\circ} \mathrm{C}$}

Proses pengisian dilakukan dengan menggunakan mesin yang dapat diatur suhunya. Suhu yang digunakan pada proses pengisian adalah $60-65^{\circ} \mathrm{C}$. Namun, saat proses pengisian, masih terdapat celah antara mesin dengan kemasan sehingga mikroorganisme yang ada di udara dapat mengontaminasi produk. Selain itu, terdapat kemungkinan bahwa suhu aktual produk tidak mencapai rentang $60-65^{\circ} \mathrm{C}$ atau bahkan melebihi rentang tersebut.Jika 
suhu aktual produk berada di bawah rentang tersebut, maka bahaya yang muncul adalah bahaya mikroorganisme. Namun, jika suhu aktual produk melebihi rentang tersebut maka bahaya yang muncul adalah bahaya kimia, yaitu terjadi proses denaturasi protein. Menurut Stuart (2005), bakteri termofilik akan mampu tumbuh dalam rentangan suhu sekitar 40$80^{\circ} \mathrm{C}$, dengan pertumbuhan optimal pada kisaran suhu $50-65^{\circ} \mathrm{C}$. Buckel et al. (1985) menyatakan bahwa protein susu seperti protein whey dapat mengalami denaturasi oleh panas, yaitu pada suhu sekitar $65^{\circ} \mathrm{C}$.

\section{Pendinginan Produk}

Produk yang sudah berada dalam kemasan masih berada dalam kondisi panas. Kemudian, produk tersebut dimasukkan ke dalam bak berisi air dingin dengan suhu sekitar $10^{\circ} \mathrm{C}$. Perlakuan dengan perbedaan suhu yang cukup ekstrim bertujuan untuk membunuh mikroorganisme dengan perlakuan thermal shock. Titik kendali kritis pada proses ini adalah kemungkinan suhu dari air dingin yang tidak mencapai $10^{\circ} \mathrm{C}$ karena hanya didinginkan dengan es batu. Jika suhu air tidak benar-benar dingin, maka suhu akhir produk dapat menjadi suhu yang optimum untuk pertumbuhan mikroorganisme.

\section{Penyimpanan Produk}

Produk yang telah dikemas, disimpan di dalam ruang pendingin sebelum didistribusikan agar umur simpan produk menjadi lebih panjang. Namun, ruang pendingin tersebut hanya menggunakan AC yang dimodifikasi sehingga suhunya dapat diatur menjadi $10^{\circ} \mathrm{C}$. Padahal, seharusnya produk disimpan pada suhu di bawah $10^{\circ} \mathrm{C}$. Menurut Koswara (2009), pendinginan dilakukan pada suhu diatas suhu pembekuan yaitu -2 sampai $10^{\circ} \mathrm{C}$. Pendinginan yang biasa dilakukan seharihari dalam lernari es pada umumnya mencapai suhu $5-8^{\circ} \mathrm{C}$. Pendinginan pada suhu di bawah $10^{\circ} \mathrm{C}$ dapat menghambat pertumbuhan mikroorganisme, sehingga produk menjadi lebih awet jika dibandingkan dengan suhu yang lebih tinggi.

Suhu akan meningkat apabila pintu dibuka dan pekerja masuk ke dalam ruangan tersebut. Suhu yang meningkat dapat menyebabkan mikroorganisme kembali aktif sehingga membuat produk menjadi cepat rusak.

\section{Hasil Pengujian Cemaran Mikrobiologi \\ Tabel 1 menunjukkan hasil pertumbuhan koloni cemaran mikrobiologipada ketiga varian produk. Sampel minuman kacang hijau (MKH) memiliki jumlah pertumbuhan koloni yang tertinggi (TBUD CFU/ml), kemudian diikuti sampel minuman kacang kedelai (MKK) sebesar3 $310^{3} \mathrm{CFU} / \mathrm{ml}$ dan susu kacang merah (MKM) sebesar $2 \times 10^{2}$ $\mathrm{CFU} / \mathrm{ml}$. Berdasarkan Pedoman Kriteria Cemaran pada Pangan Siap Saji dan Pangan Industri Rumah Tangga (BPOM RI, 2012c), uji Angka Lempeng Total (ALT) memiliki batas maksimum cemaran mikroorganisme sebesar $1 \times 10^{5} \mathrm{koloni} / \mathrm{g}$.}

Tabel 1. Nilai ALT (Angka Lempeng Total) pada produk minuma sehat berbasis kacangkacangan

\begin{tabular}{lc}
\hline Sampel & EAPC $(\mathrm{CFU} / \mathrm{ml})$ \\
\hline MKH & TBUD \\
MKK & $3 \times 10^{3}$ \\
MKM & $2 \times 10^{2}$
\end{tabular}

Keterangan:

$\mathrm{EAPC}=$ Estimated Aerobic Plate Count TBUD $=$ Terlalu Banyak untuk Dihitung $\mathrm{CFU}=$ Colony Forming Unit

Hasil pengujian ALT pada sampel MKH menunjukkan bahwa cemarannya melebihi batas maksimum cemaran mikroba, sementara sampel MKK dan MKM tidak melebihi batas maksimum cemaran mikroba. Perbedaan dalam proses pembuatan sampel MKK, MKM, dan MKH terletak pada jenis bahan yang digunakan. Sampel MKH dibuat dengan penambahan pandan dan pasta pandan, 
sedangkan sampel MKK dan MKM tidak menggunakan bahan tersebut.

\section{KESIMPULAN}

Tingkat keamanan dan sanitasi di lingkungan produksi minuman sehat di UMKM Jukajo Sukses Mulia masih tergolong cukup baik. Sumber cemaran yang paling berpotensi, terdapat pada proses produksi adalah higiene karyawan dan kebersihan peralatan produksi. Produk minuman kacang hijau memiliki cemaran mikroba yang melebihi batas standar BPOM, sementara minuman kacang kedelai dan kacang merah berada pada batas aman. Titik kendali kritis terletak pada proses filling pada saat produk akan dikemas, proses pendinginan yang terjadi setelah produk dikemas, dan proses penyimpanan sebelum produk didistribuskan.

\section{UCAPAN TERIMAKASIH}

Penulismengucapkan terimakasih kepada pemilik usaha industri rumah tangga (home industry) minuman sehat. Selain itu, penulis juga berterima kasih kepada Lembaga Penelitian dan Pengabdian Masyarakat (LPPM) Universitas Surya atas bimbinganselama penelitian dan penyelesaian naskah ini.

\section{DAFTAR PUSTAKA}

[BPOM] Badan Pengawas Obat dan Makanan RI.2011. Peraturan Kepala Badan Pengawas Obat dan Makanan Republik Indonesia Nomor HK.03.1.23.12.11. 10569 Tahun 2011 tentang Pedoman Cara Ritel Pangan yang Baik. BPOM RI, Jakarta.

[BPOM RI] Badan Pengawas Obat dan Makanan. 2012a. Peraturan Kepala Badan Pengawas Obat dan Makanan Republik Indonesia Nomor HK.03.1.23.04.12.2207 Tentang Tata Cara Pemeriksaan Sarana Produksi Pangan Industri Rumah Tangga. BPOM RI, Jakarta.
[BPOM] Badan Pengawas Obat dan Makanan. 2012b. Peraturan Kepala Badan Pengawas Obat dan Makanan Republik Indonesia Nomor HK.03.1.23.04.12.2207 Tahun 2012 tentang Tata Cara Pemeriksaan Sarana Produksi Pangan Industri Rumah Tangga. BPOM RI, Jakarta.

[BPOM] Badan Pengawas Obat dan Makanan. 2012c. Pedoman Kriteria Cemaran pada Pangan Siap Saji dan Pangan Industri Rumah Tangga. BPOM RI, Jakarta.

[BPS] Badan Pusat Statistik. 2014. Statistik 70 Tahun Indonesia Merdeka. BPS, Jakarta.

Buckle, K.A., Edwards, R.A., Fleet, G.H. and Wooton, M. 1987. Ilmu Pangan. UIPress, Jakarta.

[CAC] Codex Alimentarius Commission. 2003. General Principles of Food HygieneCAC/RCP 1-1969. Rev. 4-2003. CAC, Rome.

Effendi, A. 2017. Kasus keracunan pangan masih tinggi. (http://www.pikiranrakyat.com/nasional/2017/05/03/kasuskeracunan- pangan-masih-tinggi400404). [Diakses tanggal 20 Mei 2018].

[Kemenkes] Kementerian KesehatanRI. 2011. Peraturan Menteri Kesehatan Republik Indonesia Nomor 1096/Menkes/Per/VI/2011 tentang Higiene Sanitasi Jasaboga. Kementerian Kesehatan RI, Jakarta.

Koran Jakarta. 2016. Kesadaran standar keamanan pangan rendah. (http://www.koranakarta.com/kesadaran-standarkeamanan- pangan-rendah/). [Diakses tanggal 20 Mei 2018].

Koswara, S. 2009. Pengolahan pangan dengan suhu rendah. (http://www. bookpangan.com). [Diakses tanggal 27 Agustus 2014]. 
Putri, M. 2017. BPOM: Keamanan pangan tanggung jawab semua pihak. (http://www.republika.co.id/berita/ekon omi/makro/17/04/03/ontwdm415-bpomkeamanan-pangan-tanggung-jawabsemua-pihak). [Diakses tanggal $20 \mathrm{Mei}$ 2018].

Sanders, E.R. 2012. Aseptic laboratory techniques: Plating methods. $J$. Visualized Experiments, 63: 1-18.

Stuart, H. 2005. Essential Microbiology. John Wiley \& Sons Ltd, West Sussex.

Utami, S.P., Mulyawati, E. dan Soebandi, D.H. 2016. perbandingan daya antibakteri disinfektan instrumen preparasi saluran akar natrium hipoklorit 5,25\%, glutaraldehid $2 \%$, dan disinfektan berbahan dasar glutaraldehid terhadap Bacillus Subtilis. Jurnal Kedokteran Gigi, 7(2): 151-156. 